\title{
DIVERSIFIKASI PRODUK OLAHAN BERBAHAN SAMBAL DESA KEDUNGRAWAN KECAMATAN KREMBUNG KABUPATEN SIDOARJO
}

\author{
Ririn Febriyanti1), Oemi Noer Qomariyah²) \\ 1)Program Studi Pendidikan Matematika STKIP PGRI Jombang, Jawa Timur, Indonesia \\ Corresponding author : Ririn Febriyanti \\ E-mail : ririnfebriyanti280282@gmail.com
}

Diterima 04 September 2020, Direvisi 21 Oktober 2020, Disetujui 21 Oktober 2020

\begin{abstract}
ABSTRAK
Bisnis makanan terutama aneka bumbu dapur sangat menjanjikan. Hal ini dikarenakan beberapa faktor diantaranya yaitu banyak dari masyarakat baik di pedesaan atau di perkotaan yang bekerja sampai malam sehingga tidak sempat untuk memasak di rumah. Selain faktor tersebut, bumbu dapur juga memiliki banyak peminat dari segala macam usia dan berbagai macam kalangan. Dari faktor- faktor tersebut, harus ada inovasi yang diberikan agar ulahan aneka bumbu dapur dapat bersaing selain mempunyai rasa yang lebih enak, "Labelling" yang menarik, harga yang ekonomis, dan terdapat berbagai level tingkat pedasnya, serta aneka produk olahan yang sangat "yummy" .Tujuan dari kegiatan pengabdian adalah untuk membantu mengembangkan pemasaran baik dari segi manajemen dan sarana,prasarana mitra usaha "Arthur". Adapun permasalahan yang dihadapi mitra pengabdian masyarakat ini diantaranya adalah (1) belum diberikan kemasan yang baik pada produk kue basah yang dipasarkan dan (2) belum diberikan labelling untuk mengenalkan produknya dan yang (3) belum maksimalnya produksi yang dihasilkan. Metode pelaksanaan pengabdian yang sudah dilakukan sampai saat ini adalah pada tahapan: membantu dengan memberikan bantuan berupa alat untuk untuk meningkatkan hasil produksi aneka bumbu dapur; mengganti kemasan dengan yang lebih bagus, serta membantu membuatkan label yang menarik pada kemasan dengan mengganti label yang lama. Hasil pada tahap ini adalah semakin bertambahnya jumlah pembeli / customer dari mitra kami yakni Home Industri produk sambal Di Desa KedungRawan Kecamatan Krembung Kabupaten Sidoarjo dikarenakan labelling dan kemasan yang lebih bagus.
\end{abstract}

Kata kunci: diversifikasi; produk olahan berbahan sambal.

\begin{abstract}
The food business, especially various ingredients, is very promising. This is due to several factors, including many of the community, both in rural and urban areas, who work late at night so they don't have time to cook at home. Apart from these factors, spices also have many enthusiasts of all ages and various groups. From these factors, there must be an innovation given so that various cooking ingredients can compete in addition to having a better taste, attractive labeling, economical prices, and various levels of spiciness, as well as various processed products that are very "yummy ". The problems faced by this community service partner include (1) not yet given proper packaging for the wet cake products being marketed and (2) not yet given labeling to introduce the product and (3) the resulting production has not been maximized. The stages of the implementation of the service that have been carried out to date are at the following stages: assisting by providing assistance in the form of tools to increase the production of various cooking spices; replace the packaging with a better one, and help make an attractive label on the package by replacing the old label. The expected results at this stage are the increasing number of buyers / customers from our partners, namely the Home Industry of chili products in KedungRawan Village, Krembung District, Sidoarjo Regency.
\end{abstract}

Key words: diversification; sambal processed products.

\section{PENDAHULUAN}

Pandemi virus Corona bukan hanya sekedar bencana kesehatan, virus yang dikenal sebagai Covid-19 ini telah menimbulkan kekacauan di sektor ekonomi. Lesunya ekonomi saat ini memaksa masyarakat untuk membuka usaha sendiri atau membuka kembali membuka usahanya walaupun dengan sistem pemasaran yang berbeda. Hal ini juga dialami oleh mitra usaha "home industri olahan istilah sambal" tepatnya di desa kedungrawan 
kecamatan Krembung Kabupaten Sidoarjo yang diberi nama home industri "Arthur".

Orang Indonesia sangat tidak asing dengan sambal, dimana setiap kesempatan pasti ada aneka sambal. Cabai menjadi salah satu bahan utama yang digunakan untuk membuat sambal selain menggunakan buah tomat, dan bumbu dapur lainnya. Jenis sambal di Indonesia memang sangat beragam, dimana setiap daerahnya memiliki ciri khasnya. Karena di daerah Kabupaten Sidoarjo dekat dengan daerah laut, maka dibuatlah sambal baby cumi,sambal klotok dan sambal teri, dan sambal paru.

Mitra usaha kami dalam menjalankan bisnis sambal ini, tergolong usaha dalam skala rumahan menggunakan modal yang sedikit. Tetapi, bisnis sambal ini memiliki tingkat persaingan yang tinggi dan ketat. Sehingga dalam berjualan sambal dapat diminimalisir dengan cara harus membuat sambal dengan tingkat variasi berbeda dan unik. Mitra dalam pengabdian masyarakat ini mempunyai pelanggan tetap, maka tim pengabdi akan menambah pemasarannya dengan membuat kemasan dan label yang menarik untuk mencari pasar yang lebih beragam lagi dan membuka kesempatan kepada agen atau perseorangan yang mau menjual produk atau yang disebut reseller, sehingga akan ada banyak yang memasarkannya. Hanya saja home industri " Arthur" ini masih terkendala dalam hal pengadaan sarana dan prasarana untuk manajemen usaha, kemasan dan labelling yang kurang menarik konsumen. Oleh karena itu perlu adanya pendampingan sebagai bentuk pengabdian masyarakat dengan tujuan untuk mengembangkan pemasaran mitra usaha "Arthur" baik dari segi manajemen ataupun sarana prasarana mitra.

\section{METODE}

Metode yang digunakan dalam kegiatan pengabdian masyarakat ini dengan pendampingan dan praktik kepada mitra pengabdian sebanyak satu mitra yaitu home industry "Arthur". Adapun prosedur rencana kegiatan yang akan diberikan sebagai berikut:

a. Tahap observasi (observation), pada tahap ini tim pengabdi melakukan observasi di Desa KedungRawan Kecamatan Krembung Kabupaten Sidoarjo yang menjadi mitra program pengabdian bagi masyarakat.

b. Tahap perencanaan (Plan), pada tahap ini tim melakukan perencanaan kegiatan pelatihan dengan membuat ringkasan materi yang akan disampaikan, peralatan yang dibutuhkan sebelum dan saat proses kegiatan berlangsung. c. Tahap pelaksanaan (do), kegiatan pada tahap ini adalah memberikan wawasan kepada mitra usaha kami yang berupa pendampingan, diskusi untuk merancang kemasan yang menarik konsumen dan labeling serta pembuatan kemasan dan labelling.

d. Tahap refleksi (see), tahap ini adalah dengan rincian sebagai berikut: memberikan evaluasi/refleksi kepada mitra. $\mathrm{Hal}$ ini dilakukan untuk mengetahui seberapa jauh mitra ini bisa melaksanakan hasil dari rancangan diskusi waktu pendampingan dan memasarkan produk hasil dari mitra kami secara luas kepada konsumen.

\section{HASIL DAN PEMBAHASAN}

Adapun hasil dari kegiatan pengabdian kepada masyarakat antara lain:

a. Memberikan wawasan pendampingan dalam bidang manajemen usaha Home Industri Olahan Sambal $\mathrm{Di}$ Desa KedungRawan Kecamatan Krembung Kabupaten Sidoarjo. Adapun wawasan yang diberikan kepada home industri Olahan Cabe dan Tomat selaku mitra dalam pengabdian ini adalah bagaimana cara meningkatkan manajemen usaha, yaitu mengenai;

1. Kualitas produk,

Dalam hal ini,strategi yang diterapkan untuk membuat produk semakin berkualitas, dengan cara menampilkan atau memasang dan membuat kemasan yang "eyecathcing" sehingga mampu meningkatkan daya beli konsumen khususnya dalam pemasaran produk mitra.

2. Pemasaran,

Dalam bidang pemasaran, tim pengabdi membantu mitra dengan cara memasarkan/mengenalkan produknya untuk lebih dikenal lagi oleh masyarakat luas, yaitu dengan memanfaatkan media sosial yang ada. (baik berupa WhatsApp, Line, Facebook, Instagram). Di samping hal itu, tim pengabdi juga membuatkan banner berukuran kecil untuk memasarkan produk yang dijual dan diletakan di depan rumah. Serta membuka jaringan agen reseller untuk lebih cepat dalam mengenalkan produk mitra.

b. Pengemasan yang menarik serta membantu membuat design labelling pada kemasan produk olahan sambal Home industri Di Desa KedungRawan 
Kecamatan Krembung Kabupaten Sidoarjo. Tim pengabdi membantu dalam pembuatan kemasan yang menarik yaitu dengan memberikan wadah atau tempat yang sesuai. Tim Pengabdi juga membantu membuat design labelling pada produk yang dipasarkan oleh mitra yaitu olahan sambal klotok (gambar 1) dan olahan sambal teri (gambar 2) .

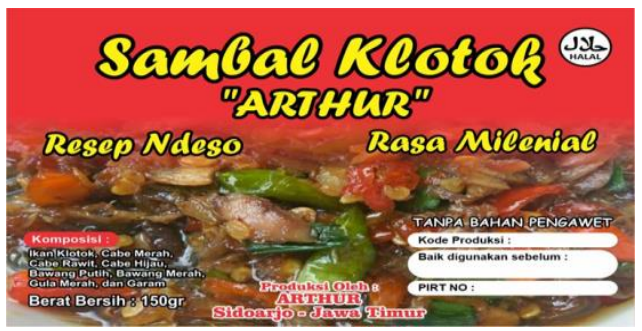

Gambar 1. Label Salah Satu Produk Olahan "Sambal Klotok Arthur"

\section{Sambal Teri : "ARTHUR"}

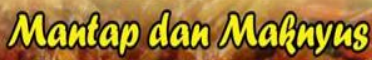

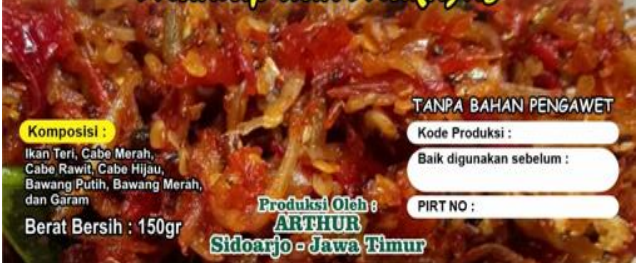

Gambar 2. Label Salah Satu Produk Olahan "Sambal Teri Arthur"

c. Pembahasan hasil pendampingan manajemen, pembuatan kemasan dan labelling. Adapun yang diperoleh dari kegiatan pendampingan ini sebagai berikut:

1. Tampilan kemasan jauh lebih rapi dari sebelumnya. Jika waktu dulu wadah atau tempatnya bumbu baik olahan sambal ataupun bumbu pecel masih kurang menarik, sekarang sudah terlihat rapi dan menarik (gambar 3 dan gambar 4). Ditunjang dengan design label terbaru menggantikan label yang lama. Di samping olahan bumbu, ternyata pada masa pendampingan mitra juga mengolah bumbu pecel dan kopi.

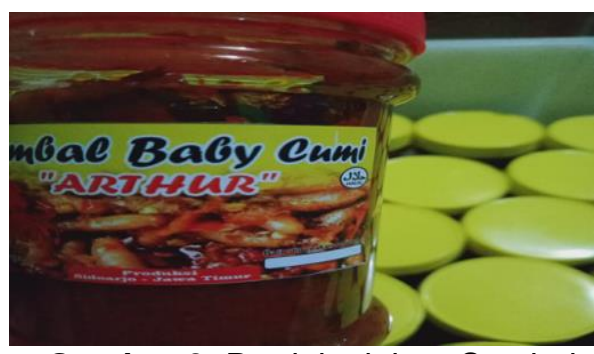

Gambar 3. Produk olahan Sambal "Baby Cumi Arthur"

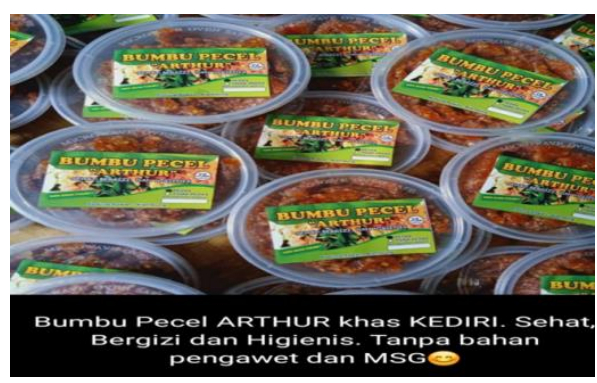

Gambar 4. Produk olahan Sambal "Pecel Arthur"

2. Dalam bidang promosi pemasaran dengan adanya banner dan media sosial, diharapkan dapat memperluas jangkauan pemasaran. Selain itu pemilik mitra juga menitipkan hasil produknya di koperasi perusahaan di sidoarjo. Adapun contoh dari media sosial berupa testimoni dari konsumen (gambar 5) dan memalui WhatsApp (gambar 6) sebagai berikut:

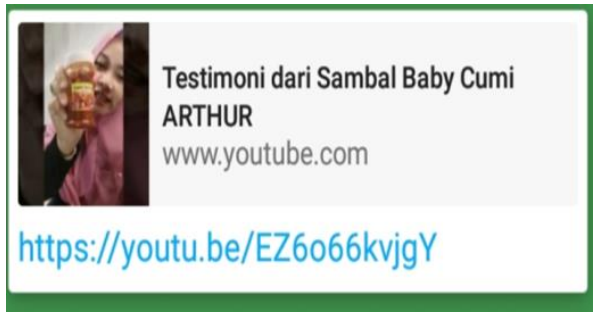

Gambar 5. Contoh Pemasaran Online

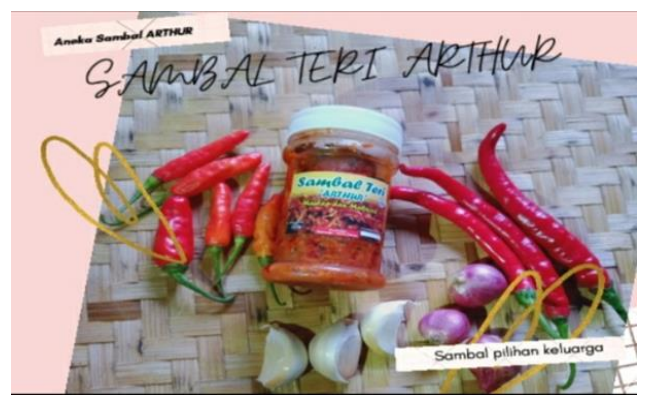

Gambar 6. Contoh Pemasaran Lewat WA

\section{SIMPULAN DAN SARAN \\ Simpulan}

Kegiatan pengabdian yang sudah dilakukan oleh tim pengabdian pada bidang 
manajemen usaha yang meliputi promosi serta kemasan dan labeling pada produk berbasis cabe dan tomat. Tim pengabdi dalam kegiatan pengabdian ini mengatasi masalah tentang produksi yaitu dengan memberikan satu unit blender guna pemperlancar dan meningkatkan hasil produksi aneka sambal. Di samping itu dalam hal kemasan, tim pengabdia berdiskusi dengan mitra untuk mebuat label kemasan yang bagus dan menarik guna meningkatkan jumlah konsumen, serta mebuat banner agar dapat diketaahui tempat usaha mitra sebagai sarana promosi.

\section{Saran}

Adapun saran dari pelaksanaan kegiatan Pengabdian ini diantaranya: Hendaknya untuk pendanaan tahun mendatang lebih besar lagi sehingga pelaksanaan kegiatan pengabdian masyarakat akan dapat lebih maksimal. Terutama membantu mitra untuk melakukan perbaikan lebih maksimal lagi.

\section{UCAPAN TERIMAKASIH}

Terimakasih kepada Pimpinan STKIP PGRI Jombang dan Tim P3M STKIP PGRI Jombang yang telah memberikan kesempatan kepada kami untuk melakukan kegiatan pengabdian kepada masyarakat, dan kepada mitra home industry "Arthur" yang berkenan untuk bekerjasama dengan tim pengabdi.

\section{DAFTAR RUJUKAN}

Alpindo, A. (2016). PENINGKATAN KUALITAS SAMBAL FERMENTASI MELALUI PENAMBAHAN GARAM DAN BAHAN PENSTABIL IMPROVING. AGRITEPA.

Ayustaningwarno, F. (2014). Teknologi Pangan; Teori Praktis dan Aplikasi. Graha ilmu.

Badan Pengawas Obat dan Makanan (BPOM). 2011. Pengawasan Klaim Dalam Label dan Iklan Pangan Olahan.

Indraswati, Denok. (2017). Pengemasan Makanan. Forum Kesehatan IImiah (Forikes).http://forikesejournal.com/ind ex.php/baf/article/view/240/114Kotler, P., \& Keller, K. L. (2009). Manajemen pemasaran Jilid 1. In Jakarta.

Kotler dan Keller. (2009). Manajemen Pemasaran. Jilid I. Edisi ke 13. Jakarta: Erlangga.

Kusnandar, F. (2010). Kimia pangan Komponen Makro. Dian Rakyat. Jakarta.

Marada, H. (2012). Pengaruh Lama Penyimpanan Ikan Cakalang Pada Suhu Freezer Terhadap Jumlah Bakteri. Skripsi. Jurusan Kesehatan Masyarakat Universitas Negeri Gorontalo.
Nugrahani, Rahina. (2015). Peran Desain Grafis pada Label dan Kemasan Produk UMKM. Fakultas Bahasa dan Seni Universitas Negeri Semarang. https://journal.unnes.ac.id/nju/index.ph p/imajinasi/article/view/8846/5795.

Oentoro, Deliyanti. (2010). Manajemen Pemasaran Modern. Yogyakarta: Laksbang Pressindo.

Riadi. M.,2013. Jurnal Definisi Usaha Kecil. Yogyakarta.

Swastha, Basu, I. (2014). Manajemen Pemasaran Modern. In Liberty, Yogyakarta. https://doi.org/10.1017/CBO97811074 15324.004 